\title{
STOCHASTIC FORECASTING ANALYSIS OF INVESTMENT FUNDS - CASE OF ALBANIA
}

\author{
Llesh Lleshaj ${ }^{202}$ \\ Alban Korbi ${ }^{203}$ \\ https://doi.org/10.31410/itema.2018.541
}

\begin{abstract}
Investment funds are financial institutions that make it possible for investors (people or businesses) to invest in their savings (or profits). The creation of investment funds is a phenomenon of the development of the financial markets of the 20th century, and nowadays. The greater the development of these funds, the more developed it is the capital market of a country. In this study we have analyzed the investment funds in Albania, represented by Raiffeisen Invest Euro. The Monte Carlo simulations of Brownian motion were used to forecast the risk return of this fund. The stochastic process techniques and the VaR model are applied to each finding of the study. Investment funds in Albania, as a new investment alternative, are not generating attractive returns for different investors. In addition to the fact that investment funds are in the start-up phase it results that their quotes have a high risk and low return. This indicates the lack of diversification and the high operating costs of the fund.
\end{abstract}

Keywords: Investment fund, Brownian motion simulation, VaR.

\section{Introduction}

$\mathrm{I}$ nvestment funds in Albania are sum of financial assets which are managed from certificated union by Financial Supervisory Authority. All of these money together form the fund assets, are invested in financial markets in Albania or in other countries, in treasury bills, treasury bonds and other financial instruments. Although it is a new form of investment, individuals are "replacing" bank deposits versus participation in investment funds. Currently on the market of investment funds in Albania, funds to carry out their activities are in the form of mutual funds. We can mention several investment funds: Raiffeisen Prestige; Raiffeisen Invest Euro; Raiffeisen Vision; and Credins Invest. The first investment fund in Albania was opened by Raiffeisen Invest in 2012 and other funds were opened later. This shows that this is a new financial investment market for the financial system in Albania. However, the interest of individuals to invest their funds is growing. In Albania there is no liquid financial market yet (stock exchanges, in function) and the alternatives of investment of money savings of individuals and businesses are limited only in some forms:

a. Bank deposits. This is the classical form of investment for individual investors in Albania, while businesses prefer to reinvest money into business plans than in bank deposits.

b. Government Instruments. This form of investment focuses on investing in treasury bills and treasury bonds. Treasury bills have a maturity up to one years, while bonds have a maturity of up to 10 years. The advantage of investing in government instruments is the fact that all government securities are guaranteed by the risk of credibility.

\footnotetext{
${ }^{202}$ Faculty of Economy, University of Tirana, Albania

${ }^{203}$ Faculty of Economy, University of Tirana, Albania
} 
c. Investment funds. Investment funds in Albania are mutual funds, which are managed by a licensed financial company. These companies are licensed by the Financial Supervisory Authority. The amount invested and the times of investment are flexible.

d. "Stock exchange on-line ". Currently, many businesses or individual investors are analyzing investment in abroad stock exchanges as an opportunity to increase their savings. These transactions are made by specialized financial companies in Albania. Some of these companies are: FX Lider, Easy Invest, etc. which are not licensed by the Bank of Albania and the Financial Supervisory Authority. These investment forms have a high bankruptcy risk (total loss of invested funds).

e. Real estate assets. This form of investment is an alternative that is used by individual investors with large savings and by businesses. The main feature of investment in real estate is the protection against inflation.

This study analyzes and forecasts the performance of the investment fund Raiffeisen Invest in Euros in Albania. This investment fund is the earliest and represents the largest share of investment funds market in Albania. In order to make analyzes and conclusions to be as current, we have analyzed the 268 days of 2018.Using the Monte Carlo simulation techniques of Brownian motion and VaR (Value at Risk) model, we have analyzed the risk and return of the investment fund. We emphasize that the results of this paper should be applied for short-term decisions and help investors understand (currently) how the risk and return is in the investment fund.

\section{Literature review}

There is no doubt that investment funds (the simplest forms of them: mutual funds) are one of the most successful financial innovations of the 20th century. Nowadays, investment funds have become a very important investment alternative of investor's savings, in developed financial markets worldwide. Due to the lack of parity rate of return in financial markets, the demand for mutual funds is essential for the development of capital markets (Lobão and Gomes, 2015).

Simple investment funds (mutual funds) have some common qualities that make them a different investment alternative from other forms for each investor (U.S. Securities and Exchange Commission, 2016). These features are:

- Professional management (professionally managed in financial terms);

- Diversification (Funds are diversified in the efficient way of risk-return);

- Low minimum investment (require a minimum investment for an investor to become part of the fund units);

- Liquidity and trading convenience;

- Costs despite negative returns;

- Lack of control (the investor does not affect the investment of financial securities);

- Potential price uncertainty (depends on the price of the financial securities where the fund is invested).

Generating revenue from investment funds depends on how funds are invested, in specific industries, or as diversified funds, Boudoukh, McAllister, Richardson and Whitelaw (2003). In the same conclusion, Goetzmann, Ingersoll and Ross (2003), have concluded that the flow of capital into the fund (and thus the growth rate of the assets) depends on changes in the fund's value and other characteristics of the fund. Thus the change in the fund's net asset value (Chevalier and Ellison, 1997). But it is not the only characteristic that changes the flow of capital into the fund, because growth rate of the assets depends on: fund size (Sirri and Tufano, 
1998), age of fund (Chevalier and Ellison, 1997), and fund type (Bergstresser and Poterba, 2002).

Investment funds are: from the simplest to the trusted ones, to the more specific ones, that are invested in specific industries of the economy or indexed on specific equity markets. As with any financial activity, investment funds are an institutional investment form where risk management is very important to them (Deloitte 2016). How the risk is managed in the investment fund? This depends on the financial structure of the fund (investment portfolio in the securities market). In a theoretical illustration, this is shown in the figure no. 1 below:

Figure no. 1. The investment fund and its dimension of risk

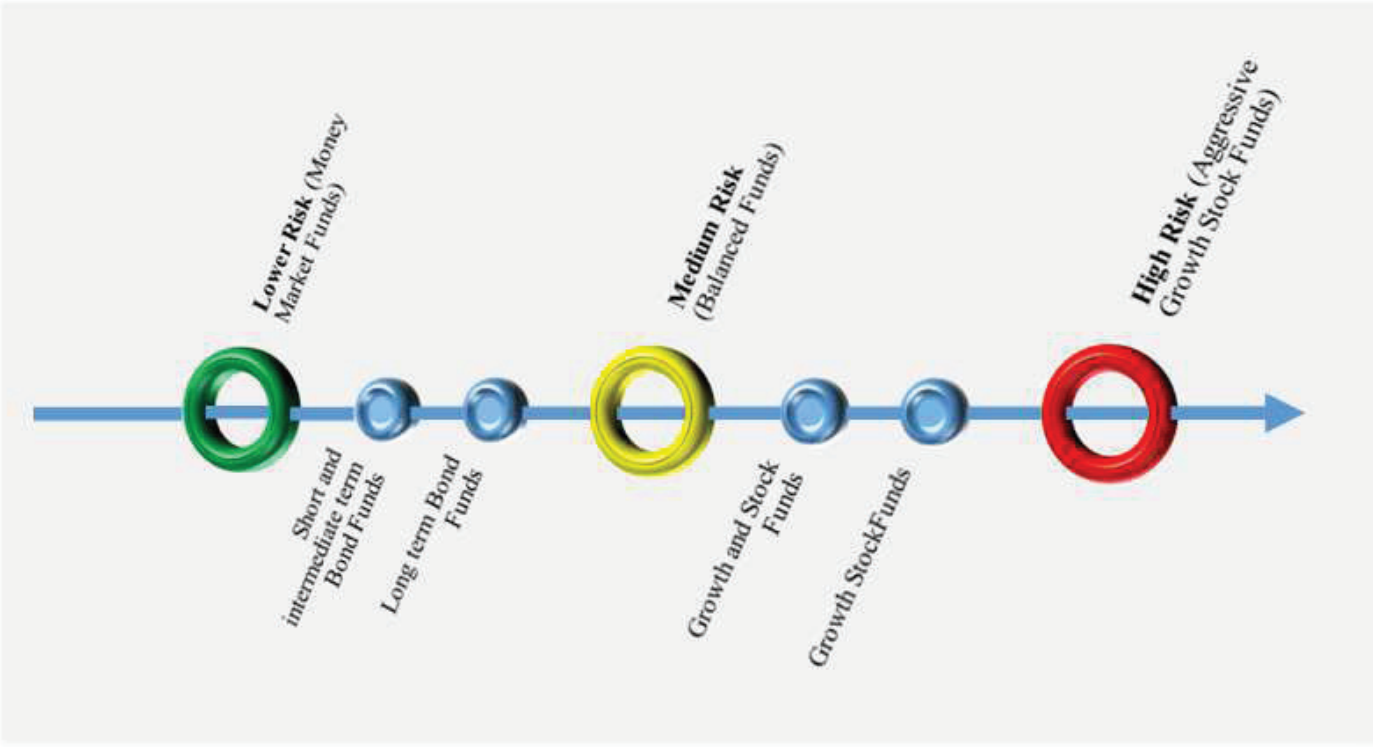

Fund performance is affected by investment strategies that are related to the well-known momentum effect in equity prices, the firm size effect, and the value premium (Engström, 2004). Investment funds are not only an investment alternative of different inventors but also develop on the financial capital market. The ability of the investment fund to achieve this great financial success depends directly on the management capability of funds. In these cases, the fund is not simply a portfolio of investments but a strategic investment fund for the financial demands of a country's capital market (Halland, Nowl, Tordo and Kloper-Owens, 2016).

\section{Methodology of study}

The data that are taken in analysis are time series (daily quotation) for 268 days of 2018. These data are based on one of the most important investment funds in Albania, the first one created in this country. The analysis included in this study is based on Monte Carlo simulations of Brownian motion, and construction of the VaR (value of risk) estimation model for the Raiffeisen Invest Fund in Euro, in Albania, applied to Microsoft Excel 2013. According to the Brownian motion simulation, the quote $\mathrm{S}$ is random walk with the characteristics:

(1) For each $0=t_{0}<t_{1}<\ldots<t_{n}$, martingals: $\mathrm{S}_{\mathrm{t} 1}-\mathrm{S}_{\mathrm{t} 0}, \mathrm{~S}_{\mathrm{t} 2}-\mathrm{S}_{\mathrm{t} 1}, \ldots, \mathrm{S}_{\mathrm{tn}-1}-\mathrm{S}_{\mathrm{tn}}$ are independents.

(2) Mathematical expectation $E\left[S_{t, i}-S_{t, i+1}\right]=0$ and variance $V\left[S_{t, i}-S_{t, i+1}\right]=t_{i+1}-t_{i}$.

Quotas are non-negative, so exponential forms of exponential functions are used to analyze the price change (or return), while the technique used in this study to measure the fund's risk is the 
VaR model. VaR (value at risk) measure the value of lowest expected loss in conditions of normal distribution market trend, for the specific interval of time and specific confidence level. How much can you lose with an $\mathrm{x} \%$ probability? The answer of this question is given by VaR (the lowest quartile of potential loses that might occur in one portfolio during a specific time.

VaR has a very substantial meaning in portfolios estimates when analyzing quantitative data with normal distribution. Based on the central limit theorem (and the law of large numbers) our data complete this feature after 268 days /observations in the analysis. If the initial investment is $\mathrm{S} 0$ and $\mathrm{R}$ return on investment, then the value of the maturity at the end of the investment holding period was by equation: $\mathrm{S}_{1}=\mathrm{S}_{0} *(1+\mathrm{R})$. VaR (relative loss vs. average) in relative terms this expected return $\mathrm{R}^{*}$ is analyzed as it deviates from the historical average, this estimate will be according to the equation $\mathrm{VaR}=\mathrm{S}_{0} *(\mathrm{E}[\mathrm{R}]-\mu)$, while in absolute terms: $\mathrm{VaR}=\mathrm{S}_{1}-\mathrm{S}^{*}$. Where $S^{*}$ is the minimum value of the invested portfolio or quartile of probabilistic distribution, under it we are at risk. If we note $\mathrm{f}(\mathrm{s})$ the probability distribution of the future value of the portfolio, VaR for defined confidence levels $k$, computes this minimum value $\mathrm{S}^{*}$ (i.e. so that the probability does not exceed the confidence level $k$ ) by equation: $\mathrm{k}=\int_{\mathrm{S}^{*}}^{+\infty} \mathrm{f}(\mathrm{s}) \mathrm{ds}$ or it calculates for this minimum level, the probability $\mathrm{p}=\left(\mathrm{s} \leq \mathrm{S}^{*}\right)$ and $1-\mathrm{k}$ is:

$$
1-\mathrm{k}=\int_{-\infty}^{\mathrm{s}^{*}} \mathrm{f}(\mathrm{s}) \mathrm{ds}
$$

A general introduction to VaR can be found in Linsmeier and Pearson (1996) and Jorion (1997). The lognormal distribution is a more reasonable distribution for many asset prices (which cannot become negative) than the normal distribution. Suppose that the return [return $=\log$ (price relative)] on the portfolio is normally distributed with annual mean $\mu$ and annual standard deviation $\sigma$ and the current value of the portfolio is $\mathrm{S}_{0}$. The logarithm of the portfolio value at time $T, S_{T}$, is normally distributed:

$$
\ln \left(\frac{\mathrm{S}_{\mathrm{T}}}{\mathrm{S}_{\mathrm{T}-1}}\right) \sim \mathrm{N}\left[\left(\mu-\frac{\sigma^{2}}{2}\right) ; \sigma \sqrt{\mathrm{T}}\right]
$$

In portfolio management the VaR calculations are interested in losses of portfolio values over a short time period (typically several days or weeks). The formula VaR above is used over any horizon of time period. $\mathrm{T}$ in formula is measured in annual terms and the daily VaR corresponds to $\mathrm{T}=1 / 360$, but in our analysis observations are measured in daily terms, so and $\mathrm{T}$ is 1 .

\section{Analysis and results}

In developed European countries, investment funds are highly developed, increasing the financial performance of capital markets. However, the differences from one country to another are obvious when we analyze the capital invested in these funds. Total net assets of European investment funds decreased by $0.5 \%$ to EUR 15,541 billion at the end of Q1 2018. Net Assets of the European Investment Fund Industry by countries (in \% of total): 
Figure no. 2. EFAMA Quarterly Statistical Release N 73 (Q1, 2018)

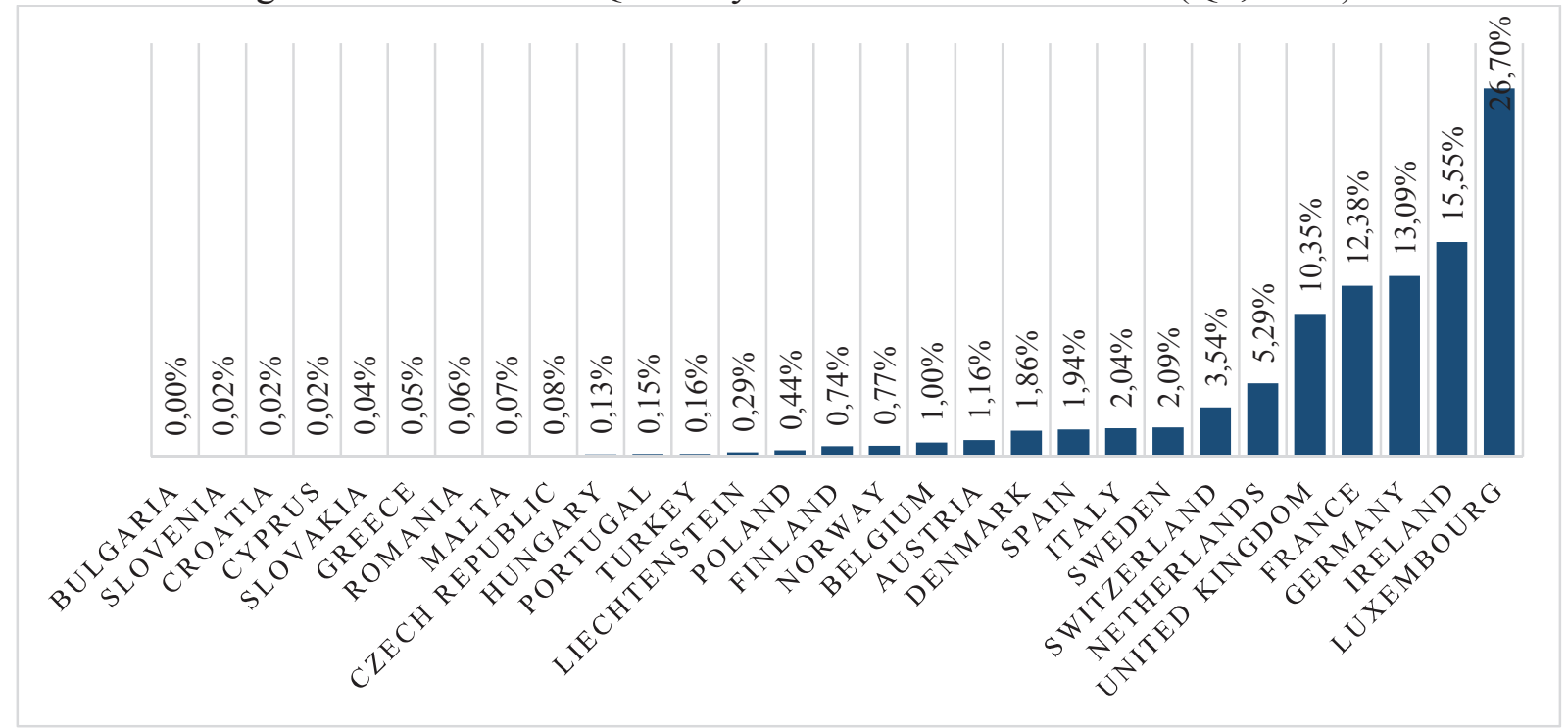

As we have said above, investment funds in Albania are a part of the financial market at their start-up stage. The largest and the earliest capital investment fund in the market is Raiffeisen Invest Euro. The minimum amount that can be invested in this fund is 250 euro's. The Fund has a portfolio focused mainly on debt securities issued by the Government of the Republic of Albania, other governments and international corporations. The Fund has also invested in investment fund quotas or shares of investment companies as another form of diversification. Fund data on 31.08.2018 (Raiffeisen Invest, 2018) show a net asset value of about 94 million euro's and the number of investors is about 4000 , with annual return $-0.38 \%$ (period 31.08 .2017 - 31.08.2018). In figure no. 3 we show how the invested capital is distributed according to the industries of the economy.

Figure no. 3. The composition of investment portfolio by industry of economy

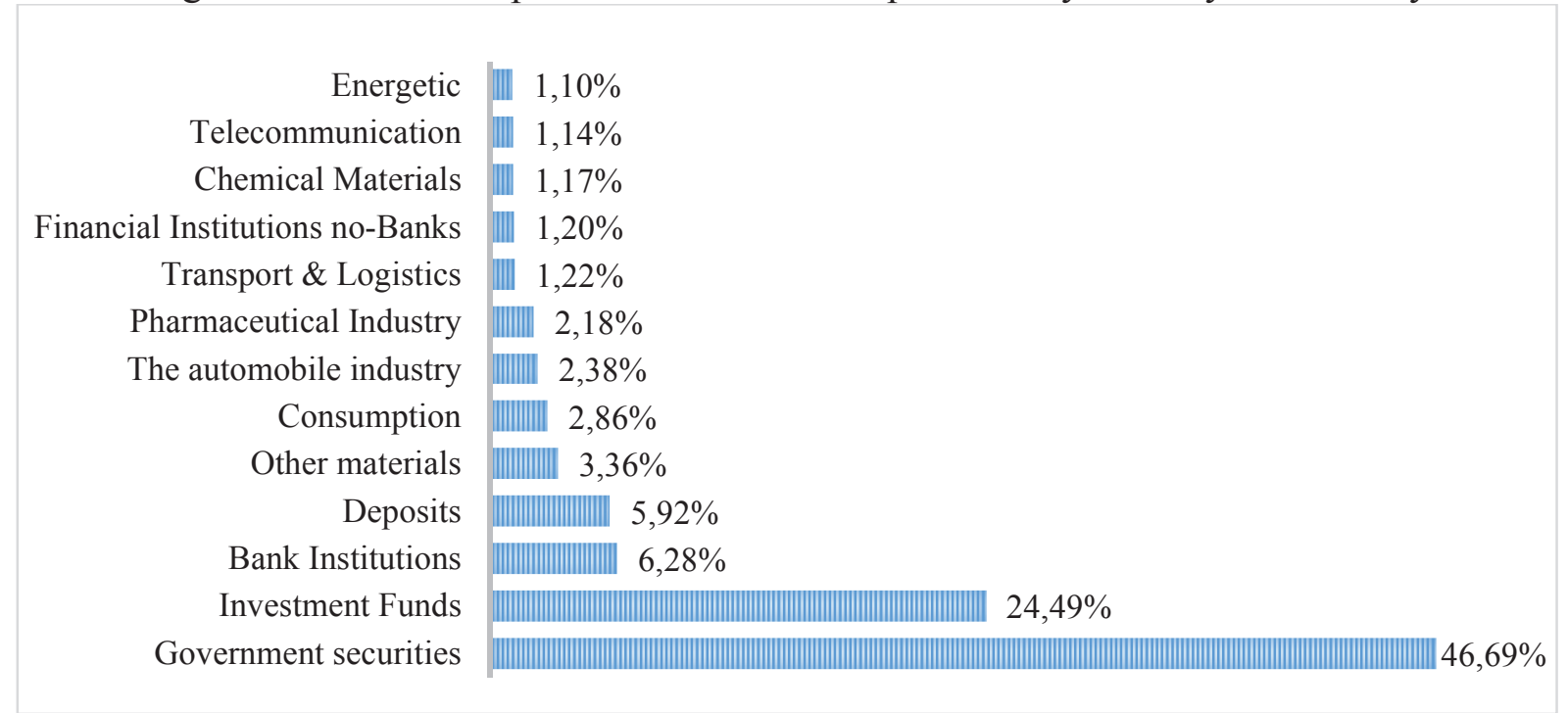

This graph shows a focus on investing funds in Government securities or other investment funds. This indicates that the level of diversification in the economy sector continues to be low, making the fund not have active diversification. In this aspect, the aim is the sustainability of quotations (a controllable and low risk), this has caused the fund to have a low return, as a result 
of the decrease in government securities yields. Therefore the average annual return rate of the fund was $-0.38 \%$.

Based on the historical quotations of the Raiffeisen Invest Euro, we have assumed that an investor invests the minimum amount allowed, 250 euro's. Using the Monte Carlo simulation method of Brownian motion, we forecasted the performance of quotas for 268 days in the future. The simulated performance of fund quotes for the forecasted days is shown in figure no. 4:

Figure no. 4. The simulated trend of price quotes by days

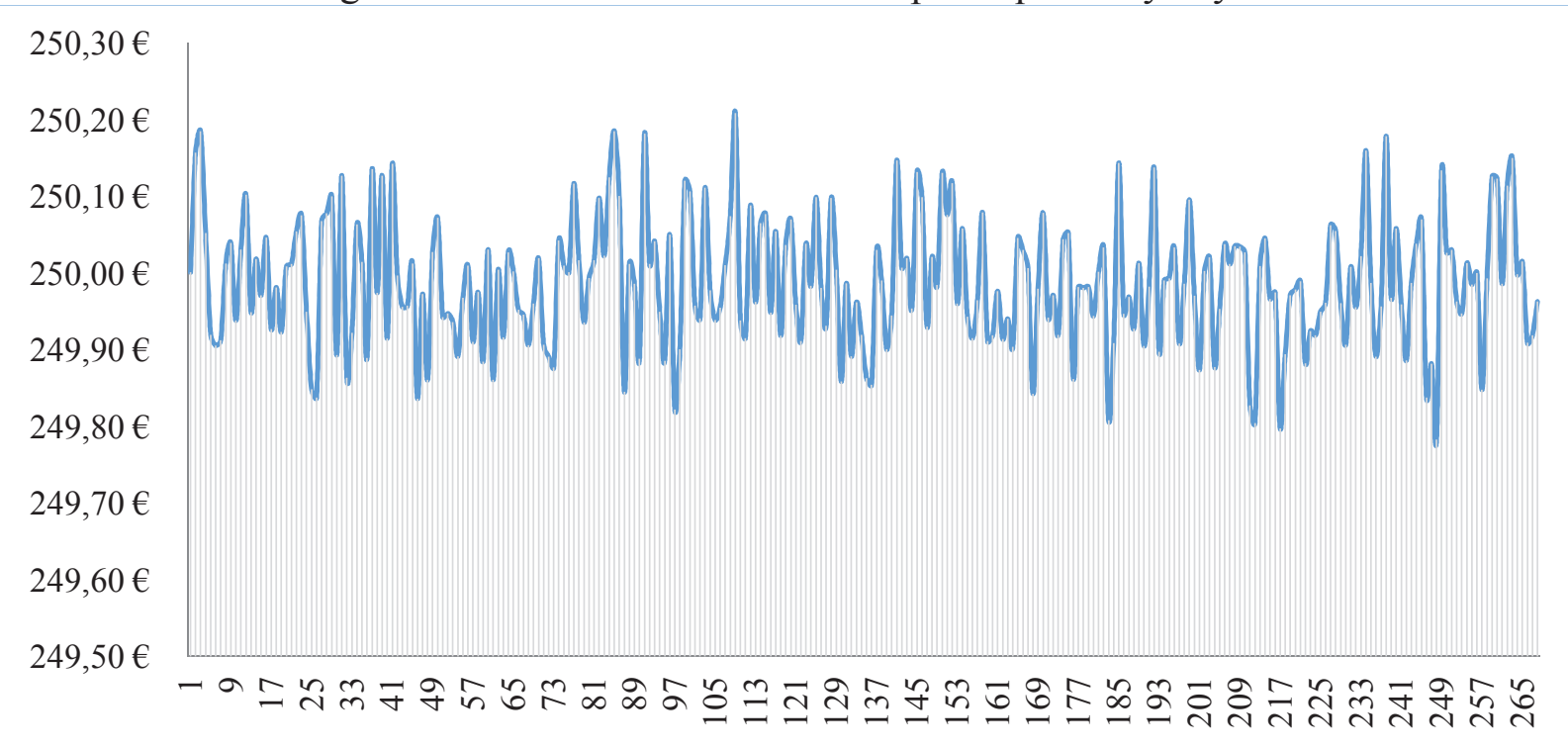

In order to explain the level of investment fund risk, diversification and risk-return potential for investors, we have used the VaR model in this paper. The results of the analysis are shown in the figure no. 5, below:

Figure no. 5. Probability density function of the fund and VaR model

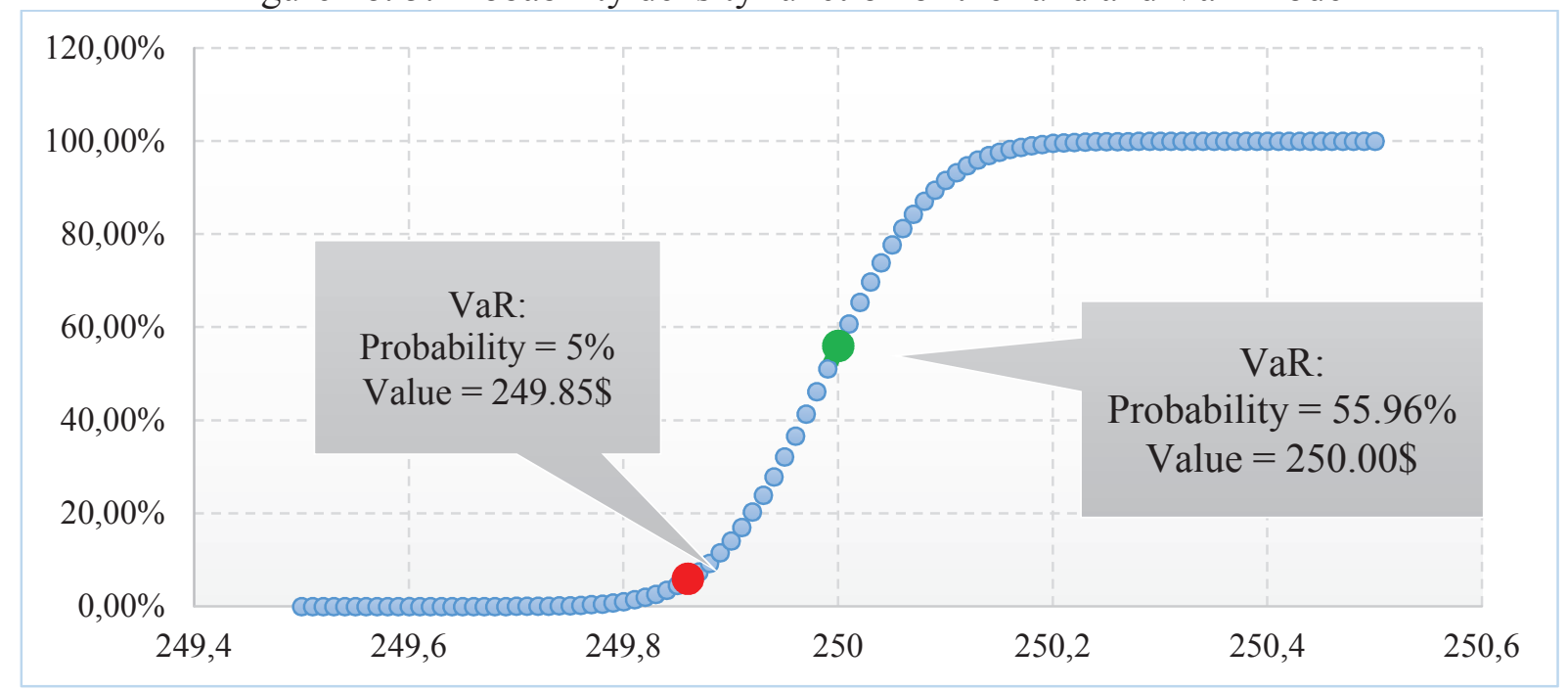

Loss of daily value (with probability $5 \%$ ) is at least $0.06 \%$ or as geometric average $24.10 \%$ is annual decreased return. This means that from the beginning of the year with the value of the fund $\mathrm{S}_{0}=250$ euro's, at the end of the year will be 189.75 euro's or the value of the risk will 
be 60.25 euro's. Looking at the chart above, $55.96 \%$ is the probability that the investment in the fund will save the initial investment value without loss. This explains that this investment alternative is very risky. This high risk makes investors not to invest their savings in funds, but continue to invest in deposits. Investment portfolio management and financial policies of fund are positioned at a high risk that does not justify return on investment.

\section{Conclusions}

The financial market in Albania is limited in terms of investment alternatives. However, in the last 5 years there are start-ups of investment funds (mutual funds). Thus, the savings of people and businesses in Albania have a new investment option. According to the financial principles it is scientifically tested that the greater the development of these funds, the more developed it is the capital market of a country itself. High interest rates on loans and very low deposit interest rates show that there is no return rate parity in Albania, therefore the development of financial investment alternatives, different from classical methods with banks is the need of the domestic market.

In this study we have analyzed the investment funds in Albania, represented by Raiffeisen Invest Euro. The daily historical quotations of 268 days of 2018 were taken into consideration. Then Monte Carlo simulations of Brownian motion were used to predict the risk return of this fund. The stochastic process techniques and the VaR model are used for each finding of the study. The study shows a short-term forecast of quotations for next 268 days.

Investment funds in Albania are in the start-up phase, instead of being characterized by high returns, they are very low, even negative, and with very high risk. The level of diversification of their portfolio is not good because they are slightly distributed in the real economy sector; they are generally supported in fixed income financial titles. The continued decrease of government debt instruments yields and the high operating costs of the fund have resulted in an average annual return rate of $-0.38 \%$. This decrease of returns is also linked to the high level of liquidity in Euros that Raiffeisen Bank has in its deposits. By VaR technique, with a probability of 5\% risk, the daily loss of quotas is $0.06 \%$ and if this loss persists, it will cause a decrease in quotas $24 \%$ (compared to the initial value at the beginning of the year). About $56 \%$ is the probability that the value at the beginning of the year in this investment fund will be the value at the beginning of the year (zero return). These are the reasons why Albanian investors begin to trust their savings (or profits) investment in bank deposits.

We recommend that investment funds must not simply be 'trusted' but must be diversified into international capital markets, reducing the share of investment in government debt instruments. On the other hand, by the economy of scale should aim to reduce the operational costs of the funds. In this way, the funds can generate satisfactory return rates for investors (especially for people) and increase their potential of development.

\section{REFERENCES}

[1] Benninga S. (2008). Financial Modelling, $3^{\text {rd }}$ edition, MIT Press.

[2] Bergstresser, D., and J. Poterba (2002). Do After-Tax Returns Affect Mutual Fund Inflows? Journal of Financial Economics 63, 381-414.

[3] Bernstein Sh., Lerner J., Schoar A. (2009). The Investment Strategies of Sovereign Wealth Funds. Harvard Business School, Working paper 09-112

[4] Boudoukh J., Richardson M., Stantonand R., Whitelaw R. (2004). Valuing Mutual Fund Companies, University of California: Fisher Center Working Papers 
[5] Boudoukh, J., P. McAllister, M. Richardson and R. Whitelaw (2000). The Valuation and Hedging of Deferred Commission Asset Backed Securities, working paper, New York University.

[6] Chevalier, J., and G. Ellison (1997), Risk Taking by Mutual Funds as a Response to Incentives, Journal of Political Economy 105, 1167-1200.

[7] EFAMA (2018). Trends in the European Investment Fund Industry in the First Quarter of 2018, No. 73

[8] Engström S. (2004). Investment Strategies, Fund Performance and Portfolio Characteristics, SSE/EFI Working Paper Series in Economics and Finance, No. 554

[9] Goetzmann, W., J. Ingersoll, and S. Ross (2003). High Water Marks, and Hedge Fund Management Contracts, Journal of Finance.

[10] Halland H., Nowl M., Tordo S., Jacob J. Kloper-Owens (2016). Strategic Investment Funds: Opportunities and Challenges, World Bank Group, Finance and Markets Global Practice Group, Policy Research Working Paper 7851

[11] Kraemer-Eis H., Schillo M. (2011). Business Angels in Germany: EIF's initiative to support the non-institutional financing market, European Investment Fund, Working paper.

[12] Learn L. (2016). "Introduction to Investment Funds", Deloitte Belgium

[13] Lobão J., Cruz Gomes S. (2015). Performance and characteristics of mutual funds: evidence from the Portuguese market, Revista de Gestão, Finanças e Contabilidade, ISSN 2238-5320, UNEB, Salvador, v. 5, n. 4, p. 125- 148.

[14] Raiffeisen INVEST (2018). Raport Muaji Gusht 2018

[15] Sirri, E., and P. Tufano (1998). Costly Search and Mutual Fund Flows, Journal of Finance $53,1589-1622$.

[16] U.S. Securities and Exchange Commission (2016). Mutual Funds and ETFS A Guide for Investors, Office of Investor Education and Advocacy 100 F Street, NE Washington, DC 20549-0213

[17] Wiener Z. (1998). "Value-at-Risk (VaR)" Mathematics in Education and Research, Vol. 7, pp. 39-45. 